\title{
VISUAL ART FROM THE PERSPECTIVES OF ISLAMIC SHARIAH: A NEED ASSESSMENT ANALYSES
}

\author{
Ishak Ramli ${ }^{1 \star}$, Mohamad Noorman Masrek ${ }^{2}$, Muhamad Abdul Aziz Ab Gani ${ }^{3}$, D’Zul \\ Haimi Md Zain ${ }^{4}$, Muhamad Rahimi Osman ${ }^{5}$, Mumtaz Mohktar ${ }^{6}$, Suhaimi Tular ${ }^{7}$ \& \\ Zarlina Mohd Zamri ${ }^{8}$ \\ ${ }^{1}$ Mr., Faculty of Art \& Design, Universiti Teknologi MARA, Perak Branch, Seri Iskandar Campus, \\ MALAYSIA, ibr_86@yahoo.com \\ ${ }^{2}$ Assoc. Prof. Dr., Faculty of Information Management, Universiti Teknologi MARA, MALAYSIA, \\ mnoormanm@gmail.com \\ ${ }^{3}$ Dr., Faculty of Art \& Design, Universiti Teknologi MARA, Perak Branch, Seri Iskandar Campus, \\ MALAYSIA, duzeezdugani_designstudio@gmail.com \\ ${ }^{4}$ Prof. Dr., Faculty of Art \& Design, Universiti Teknologi MARA, MALAYSIA, \\ dzul@salam.uitm.edu.my \\ ${ }^{5}$ Prof. Dr., Academy of Islamic Contemporary Studies, Universiti Teknologi MARA, MALAYSIA, \\ rahimi131@salam.uitm.edu.my \\ ${ }^{6}$ Dr., Faculty of Art \& Design, Universiti Teknologi MARA, MALAYSIA, \\ mumtaz@salam.uitm.edu.my \\ ${ }^{7}$ Mr., Faculty of Art \& Design, Universiti Teknologi MARA, Perak Branch, Seri Iskandar Campus, \\ MALAYSIA, suhai815@perak.uitm.edu.my \\ ${ }^{8}$ Ms., Academy of Language Studies, Universiti Teknologi MARA, Perak Branch, Seri Iskandar \\ Campus, MALAYSIA, zarlinamz@gmail.com \\ ${ }^{*}$ Corresponding author
}

\begin{abstract}
Based on the previous studies on issues concerning visual artwork, many suggested an improvement has to be made on the Guidelines about Visual Art from the Islamic Perspectives (1987). Referring to the guideline, the process of producing visual artwork deals with the visual subject and the style of presenting the visual form. As a reference in producing Shariah compliant visual artwork, the guideline should be improved based on the evolving of the contemporary art. This paper aims to explore the needs of study on visual art from the perspectives of Islamic Shariah base on the contemporary development in the art scene. Given this gap, this study attempts to discuss the literature review for compiling the preliminary view point on the guideline status quo. The result shows that there are deficiencies in the guideline in terms of visual subject, visual form and visual content discussion. It is hoped that this study will pave the way to new frontier in the Contemporary Visual Art based on Islamic Shariah which has a huge contribution to the sustainability of national art. Result of this study can become a literature for those researchers who are intent to discover on this topic. Recommendation was given for further investigation into a refinement the guideline base on the contemporary art development through the qualitative research.
\end{abstract}

Keywords: Visual Art, Islamic Shariah, Need Assessment 


\section{INTRODUCTION}

Visual art is a constantly progressing field from the perspective of visual, philosophical comprehension, media innovation and material as well as many others. Nevertheless, in its progressive development, visual art must be shaped from a strong fundamental in Islamic teachings. Any visual art which deviates from the teaching and learning of Islam must be avoided especially among muslim artists. However, there are artifacts produced that portray questionable visuals in terms of their acceptance in Islam. Similar issues were discussed by Ahmadrashidi (2010a), who criticized some artists' behaviour that defy Islamic Shariah in the development of miniature art from Islamic civilization in India.

Malaysian visual art scene development also faces the same predicament. Despite efforts taken by local Islamic organizations to produce a guideline for guidance, in the capacity for ideas and innovation, some Malaysian visual art artists still produce artwork which are not Shariah compliance. In another issue, the guidelines must be improved in line with the latest development since there are artwork produced without prior discussion. Thus, this paper aims to explore the needs of study on visual art from the perspectives of Islamic Shariah base on the contemporary development in the art scene.

\section{AN OVERVIEW SCENARIO ON THE VISUAL ART IN MALAYSIA: SHARIAH AWARENESS AND ARTIST BEHAVIOUR}

Generally, in Malaysia, many artists often produce artwork in the Western visual language. Malaysian education during its post-independence years transformed from the traditional or madrasah and vernacular system to modern education from the West. As a result, many local students went to pursue their studies abroad to obtain formal education from the foreign countries. One of the fields which was part of the main choice of education in the West was visual art field. This situation was apparent when there was scholarship offered from the state governments and various foreign scholarships for those who were interested to take up visual art studies. Malaysian artists who received formal education from the west through scholarship were Sulaiman Esa, Syed Ahmad Jamal and Redza Piyadasa (only to name a few). As a result, changes in the visual art movement in Malaysia could be seen in the artwork style which used Western visual language (Muliyadi Mahamood, 1993). Nevertheless, the Malaysian visual art scene suffered a conflict when there were some artwork exhibited clearly contrasted with the local society's visual culture. Such situation occured among the Malaysian visual art scene because it was still in the process of assimilation or adoption of Western visual culture into their artwork.

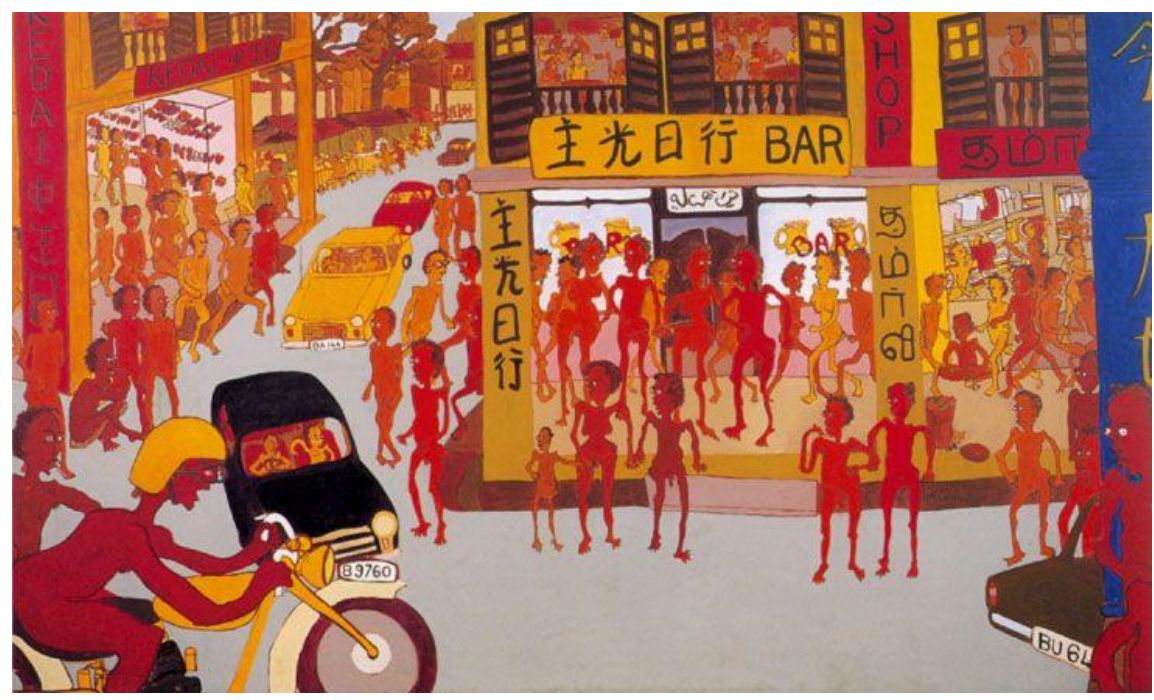

Fig. 1.1: Kedai-kedai, 1973.

1970s era was a decade full of controversies in the exhibition of Malaysian visual art. Zulkifli Dahlan had produced a visual art piece which portrayed several naive artwork or cartoon (to show an example, refer to Fig. 1.1) (Muliyadi Mahamood, 2001). It showed the situation in a busy town which was bustling with activities. Unfortunately, the figures portrayed in the artwork were nude and this caused uneasiness among visual art followers in terms of cultural values and local Islamic beliefs.

Several years later, Waiting for Godot which was produced in 1977 by Sulaiman Esa also attracted controversies (Khatijah Sanusi, 2011). Its composition that placed two contrasting subjects caused discomfort among local visual art admirers at that time. Main discussion on Waiting for Godot centered on the formation and images used since they were non-Shariah compliance. The woman featured in the artwork 
was naked and on the background, arabesque art which had kufi calligraphy art with Allah inscripted in it, was placed upside down. (Refer to Fig. 1.2).

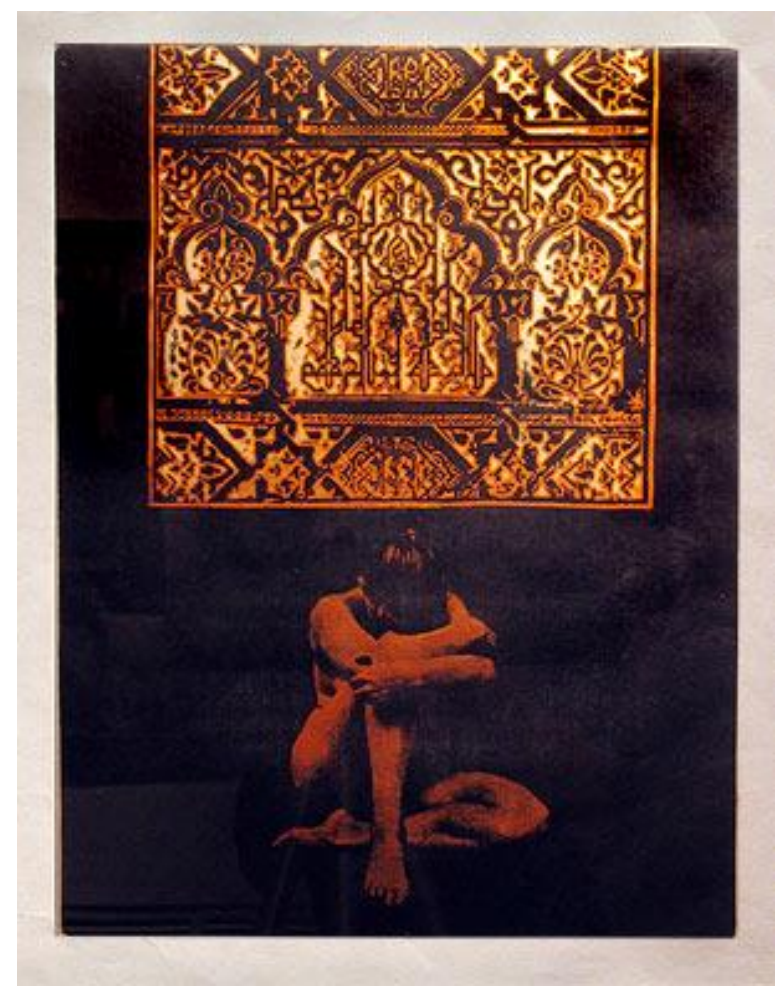

Fig. 1.2: Waiting for Godot, 1977.

Having presented the discussion above, the researcher realized that there are artwork which can be questioned in terms of its visual use from the context of Islamic Shariah. Therefore, a study which is focused on the use of Shariah compliance visuals must be conducted. Portrayal of this artwork could have been based on good intentions such as social criticism: but in Islam something that is not right cannot be used even for good intention. SyeikhYusuf Qaradhawi (1989) stated that "good intention is not an excuse for something that is haram". In other words, the statement emphasized Islam's firmness in dealing with the issue of haram - it remains haram despite the original good and noble intention. Syeikh Yusuf also stressed that, Islamic Shariah prohibits and rejects the belief in al-ghayah tubarrirul wasilah (in the pursuit of goals, any method is justified) or al-wushulu ilal haq bil khaudi fil katsiri minal bathil (to obtain something good, one can do anything even if it is wrong) (Ishak et al. in press, Yusuf Qaradhawi, 1989, p. 39).

In addition, this research also refers to several studies related to visual art and Islam. These researches are focused on several discussions in the introduction and literature review. However, the researcher does not emphasize on the findings in these researches. In a doctorate thesis entitled "Safavid Qur'an: Style and Illumination", Dzul Haimi Md Zain (1997, p. 3) discussed the beauty of al-Qur'an's illumination which is supposed to provide a refelction on Islamic Shariah understanding. Its discussion revolves around the comparison of al-Qur'an decorative art during Islamic era known as Safavid. Nevertheless, matters pertaining visual art according to Islamic Shariah is not discussed in detailed. Sulaiman Esa $(1997$, p. 85) in his doctorate dissertation entitled "Islam and Politics of Art in Post-Independence Malaysia" covers the issues of Islamic Shariah from its fundamental perspective through figh muamalat. Its statements provide explanations on divisions of figh muamalat as a necessity in social responsibilities. Description on Islamic Shariah is general and there is no specific study which is related to visual art in Islamic Shariah.

As for Khatijah Sanusi's doctorate thesis (2000, p. 17) entitled "Visual Art Education in Malaysia", it stated, generally, the influence of al-Qur'an and al-Hadith has transformed the shape of Malay community art. In her research, there are statements which are related to prohibitions expressed in hadiths related to portrayal of naturalistic or representation. These matters lead to stylization method or denaturalization in the process of producing visual art pieces. However, her thesis does not specifically discuss the perspective of Islamic Shariah in visual art. Ahmadrashidi (2010b) in his doctorate thesis "Contemporary Islamic Painting in Malaysia 1980 - 2000" also covered the matters on references in artwork production which has to take into consideration the al-Qur'an dan al-Hadith. The thesis also discussed negative attitudes among artists in producing visual art materials which do not adhere to the belief, needs, understanding, rules and regulation 
as well as norms in Islam. Ahmadrashidi presented various Islamic perspectives related to the visual art. The author also stated that many scholars agreed that Islamic Shariah and Fiqh are formulas in producing and evaluating visual art. However, specific discussion on visual art through the eyes of Islamic Shariah was not included.

As a whole, Dzul Haimi, Sulaiman, Khatijah and Ahmadrashidi only provided general academic discussion on the place of visual art in Islamic Shariah. Focus on visual art in the perspective of Islamic Shariah was not the centre of their studies.

\section{VISUAL ART FROM THE PERSPECTIVES OF ISLAMIC SYARIAH}

Islamic Shariah is a mandatory issue in discussing each aspect of life. Similarly, visual art is also an integral part of the discussion when it comes to Islamic Shariah. Looking in depth at visual art and its position in Islamic perspective, it is placed in the division of Shariah under the context of figh muamalat which involves human social relationships (Sulaiman Esa, 1997). In Islam, the purpose or Maqasid in Shariah is something that leads to maslahah (good) and it protects from mafsadah (bad) through religious rules or regulation (Hanifah Musa \& Mashita, 2012). There are three levels or significance in the Islamic laws based on Maqasid Shariah which are: 1) Major needs [ad-Dharuriyyat] which are a must in handling with religious and worldly maslahah. If there is none, worldly maslahah would not be dealt in the right way, which causes destruction in the life now and in the hereafter; 2) Needs [al-Hajiyyaf] are things which connect humans with other God's creations since they cannot leave survive on their own; 3) Beauty and perfection [at-Tahsiniyyat or alKamaliyyat] are things ruled out by Allah in order to improve humans' lives that lead to perfection and enhancements (Abdul Azib Hussain, 2012, p. 208 - 213). In Maqasid Shariah, visual art is seen as being under the level of beauty or perfection [at-Tahsiniyyat atau al-Kamaliyyat] that is a situation to enhance humans' lives to the utmost condition (Syamsul Anuar, 1995). Nevertheless, visual art will take a central position to "major needs" [ad-Dharuriyyat] when there are negativities (mafsadah) in the use of visuals which are improper in their production.

Based on the same context, Osman Bakar (1993, p. 9) stressed that in dealing with Islamic manifestation in art, I believe that we cannot escape from the dispute of meaning and form. This is because when we discuss form in Islam, we have to adhere to certain rules and regulations. One of the main factors which influences this is the Shariah. As Muslims, we have to embrace all Shariah principles and as long as we remain steadfast to the Shariah, we have to accept that in art, these are the same principles which determine suitable approach to art.

Osman Bakar's explanation stressed that the major need in the discussion on visual art must be taken from the aspect of form according to Shariah principles. Some forms which are found in visual arts are either prohibited, banned or not encouraged have been around for so long. These are not stumbling blocks to Muslim artists to express freedom in producing their artwork: true Muslim artists must adhere to the boundaries available within the religious belief. In fact, this paves the way for the artists to explore others areas in producing their art (Osman Bakar, 1993, p. 10).

\section{THE COMPARISON BETWEEN THE STUDY OF VISUAL ART IN THE PERSPECTIVES OF ISLAMIC SHARIAH AND ISLAMIC ART}

Based on the above discussion between Islamic Shariah and visual arts, the emphasis is given to the research on visual art from the perspective of the Shariah which is slightly different with research on Islamic art. Islamic art generally portrays images such as flora, patterns or any art which is not based on objects (Wan Samiati, Dzul Haimi, Rahman 2013, p. 2). Statements related to Islamic art also bring us to the concept of Tauhid and this leads us to two main terms which are "art" and "Islam". According to Syed Ahmad Jamal and supported by Dzul Haimi Md Zain (Wan Samiati et al. 2013, p. 6) Islamic Art can be defined as an artwork or art object which is produced and owned by Muslims. Below is the emphasis given in the visual art research according to Islam as compared to research in Islamic Art: 
IJASOS- International E-Journal of Advances in Social Sciences, Vol. III, Issue 7, April 2017

Table 1. Research Components in "Visual Art in the Perspectives of Islamic Shariah" in contrast to "Islamic Art"

\begin{tabular}{|c|c|c|}
\hline $\begin{array}{l}\text { Visual Arts from the perspectives of } \\
\text { Islamic Shariah }\end{array}$ & $\begin{array}{l}\text { Components } \\
\text { which are } \\
\text { compared }\end{array}$ & Islamic Art \\
\hline $\begin{array}{l}\text { Surrounding subjects (human, animals, } \\
\text { man-made items) are made into } \\
\text { references for artwork } \\
\text { (Ishak et al. in press) }\end{array}$ & Subject & $\begin{array}{c}\text { Subjects are flora or fauna, patterns or } \\
\text { objectless art } \\
\text { (Wan Samiati et al. 2013) }\end{array}$ \\
\hline $\begin{array}{l}\text { Naturalist (direct portrayal or full } \\
\text { representation), Realist (emotions in } \\
\text { exhibiting or representing artwork), } \\
\text { semi-abstract (half-clear image which } \\
\text { has been simplified and altered or half- } \\
\text { representation) and abstract (completely } \\
\text { altered visual) } \\
\text { (Ishak et al. in press) }\end{array}$ & Form & $\begin{array}{c}\text { Stylization or Abstract in nature. } \\
\text { Goes through the process of } \\
\text { production from naturalist to stylization } \\
\text { to abstract } \\
\text { (Dzul Haimi Md Zain, 2003) }\end{array}$ \\
\hline $\begin{array}{c}\text { Object, subject or image or visual which } \\
\text { are allowed or banned according to the } \\
\text { Islamic Shariah based on Malaysia } \\
\text { Visual Art } \\
\text { (Ishak et al. in press) }\end{array}$ & Discussion & $\begin{array}{l}\text { Collection of art artifacts from the } \\
\text { Islamic civilizations era which are made } \\
\text { as references in the development of } \\
\text { Islamic art concept (there are also } \\
\text { artwork which seem to defy Islamic } \\
\text { Shariah) } \\
\text { (Ahmadrashidi Hassan, 2010a) }\end{array}$ \\
\hline
\end{tabular}

Comparisons which are made in the table clearly shows that there are differences in the context of visual art studies according to the Islamic Shariah and Islamic art. Wan Samiati et al. (2013) and Ahmadrashidi (2010b) stated that any artifact which originated from the context of form and meaning which align with the teaching and learning in Islam, the artifact can be categorized as "Islamic art". In contrast, the discussion on visual art is the opposite of this in terms of Shariah law. This study is not putting labels on arts as "Islamic art" but it is focused on the use of "subject" and "form" as a method that comply with the Shariah. Any reference which for example is taken from the West, East, China, India as well as the aboriginal art from any part of the world, as long as they can be moulded to adhere to Islamic Shariah, they must be accepted.

\section{THE NEEDS OF ASSESSMENT ON THE GUIDELINES AND EXPLANATION ON VISUAL ART FROM THE ISLAMIC'S PERSPECTIVE (1987): AN OVERVIEW ANALYSES}

Therefore, the researcher will focus on researches which are related to visual art according to Islamic Shariah. Visual art according to the Islamic Shariah will be discussed in depth through the fiqh muamalat in order to improve the existing guidelines as a form of guidance for the Malaysian community and the world at large. Existing guidelines were compiled on 1987, based on the decision made by Majlis Kebangsaan HalEhwal Ugama Islam Malaysia (MKI) (now known as JAKIM - Malaysian Islamic Development Department) through one discourse related to visual art. Discussion by the committee of Fatwa had successfully produced "Guidelines and Explanation on Visual Art from the Islamic's Perspective" (Jabatan Kemajuan Islam Malaysia, n.d.). Nevertheless, after 30 years have passed, the guidelines have to be re-examined form the perspective of visual art practitioners and an expert in Islamic Shariah based on current issues (Ishak Ramli, Mohamad Noorman Masrek \& Muhamad Abdul Aziz Ab Gani, in press; Ishak Ramli et al. 2014; Ishak Ramli et al. 2012).

Based in the latest situation in Malaysian visual art, the researcher believes that the guideline can be further improved. Existing guideline focused on two major areas: 1) Hukum/Regulation that are listed must be harus and haram; 2) Different types of art namely painting (two dimensions) and the sculpture/carvings (three dimensions). Below are the guidelines: 
IJASOS- International E-Journal of Advances in Social Sciences, Vol. III, Issue 7, April 2017

Table 2. Guidelines and Explanation on Visual Art from the Islamic's Perspectives (1987)

\begin{tabular}{|c|c|}
\hline HUKUM & TYPES OF PAINTING \\
\hline $\begin{array}{l}\text { Harus/ } \\
\text { Encouraged }\end{array}$ & $\begin{array}{l}\text { - Draw/retrieve pictures ofwell-known icons for the purpose of history } \\
\text { - Draw/snap pictures of lifeless things such as trees, sceneries, tools and other } \\
\text { related items } \\
\text { - Draw/snap pictures of living objects to be worshipped and idolised. (Objects } \\
\text { which are not prohibited) } \\
\text { - Draw/snap pictures on objects which are not worshipped whether or not they are } \\
\text { lifeless (humans, animals and plants) }\end{array}$ \\
\hline Haram & $\begin{array}{l}\text { - Draw pornographic material/humans with compromising aurah } \\
\text { - Draw lewd images of animals } \\
\text { - Draw something to be worshipped or idolized } \\
\text { - Draw any object which represent non-Islamic religious beliefs, that are } \\
\text { blasphemous } \\
\text { - Draw an object with an intention to challenge Allah SWT's creation } \\
\text { - Draw pictures of angels, prophets, and the Sahabah (10) who were promised } \\
\text { haven } \\
\text { - Draw icons, leaders or nobles for the purpose of worshipping them for soul- } \\
\text { cleansing }\end{array}$ \\
\hline HUKUM & TYPES OF SCULPTURE/CARVING \\
\hline $\begin{array}{l}\text { Harus/ } \\
\text { Encouraged }\end{array}$ & $\begin{array}{l}\text { - Carve humans, and animals in the form of covering their aurah or modest for } \\
\text { Children's toys, education and teaching and learning as well as knowledge. } \\
\text { - Carve non-living objects such as trees and buildings as well as others }\end{array}$ \\
\hline Haram & $\begin{array}{l}\text { - Carve any type of human and animals even in the form of covering their aurah or } \\
\text { being modest for any purpose except for toys, education and teaching and } \\
\text { learning. }\end{array}$ \\
\hline
\end{tabular}

Malaysian visual art history has shown tremendous change in the production and exhibition of artwork: from visuals which recorded scenes from nature to abstract paintings. Most of the images which were recorded were single subject (it is not changed or combined). Creativity and innovation have brought visual art artists into the production of different artwork from what was normally observed with the existence of combined or hybrid subjects. This was exemplified in artwork of Jalaini Abu Hassan entitled The Raging Bull in 2015 (as an example, refer to Fig. 1.3) (Galeri Wei-Ling, 2015). This artwork portrays the subject of a man in his sarong who is standing but his head is of a cow with horns. Next to him is a pig charging towards him.

Human with a head of a cow is an alien subject or something that is out of the norm in the production of a visual. Featuring a pig in that artwork is something that is against the society's cultural sentiment in Malaysia, particularly the Malays. However, a subject like this is not discussed in the guideline which was produced in 1987. Most probably, images as such (in Figure 1.3) had not been produced and exhibited at that time. Some of the questions which could be brought forward are: 1) What is the place of an art which combines man and animal in Islamic Shariah? 2) What is the rule about drawing a pig (which is against the Malay's sentiment) in Islamic Shariah?

Situations which are mentioned earlier have changed the place of visual art in the context of Maqasid Syariah (from the perspective of Islamic law) from the level of "beauty and perfection [at-Tahsiniyyat or alKamaliyyat]" to the postion of "main need [ad-Dharuriyyat]" to be studied. Visual art from the perspective of Maqasid Syariah aims to perfecting and improving human's life. Nevertheless, if there is any visual used which is against the Islamic regulations, the matter must be avoided. Even though JAKIM (Malaysian Islamic Development Department) has provided the guidelines, constant changes in the visual art scene call for another evaluation. 


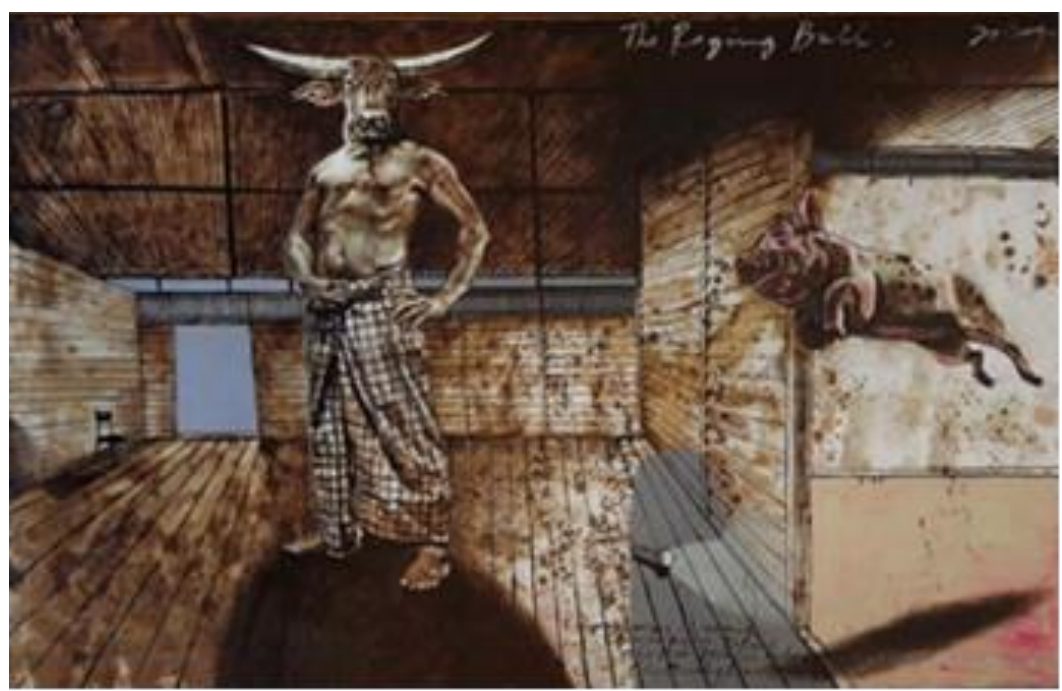

Fig. 1.3: The Raging Bull, 2015.

Efforts to further improve the guidelines in detail are an integral effort in the current visual art scene. This has to be done to prevent Malaysian visual art artists, generally and Muslims specifically from breaching the Islamic Shariah laws in future production of their artwork. Malaysia as an Islamic country has to improve the existing guideline with regard to visual art and others too according to current demands.

\section{CONCLUSION AND RECOMMENDATION}

This research will look into details all the components in the visual art namely: 1) [Subject]; 2) [Form]; and 3) [Content]. These three components are the major part in many discussions such as studies in literature, performing art, theatre and many more (just to name a few). These universal components make them applicable into many areas. In the field of visual art, Ocvirk, Stinson, Wigg, Bone, and Cayton, (2009, p. 11) had discussed "The Three Basic Components in Visual Art". These components are similar to those mentioned earlier namely subject, form and content. Therefore, by using the same components, the researcher would like to suggest that the sub-components which must be given an in depth study are: 1) Sub-component for "subject" which is living things [humans and animals], non-living things [nature and manmade items] and a combination of all [among humans, animals, nature and made-made items]; 2) Subcomponent for "form" is the full representational, semi-abstract and abstraction; and 3) Sub-component for "content" is the issue which is brought forward and message that needs to be conveyed. However, in this research, focus will be given to discussions on the "subject" and "form" components as well as their subcomponents. The researcher who is interested in giving an in-depth study of this issue could use qualitative research method. Content analysis is seen as the most suitable research strategy for the process of semistructured interview to identify and improve visual art components. In addition, similar research method can be used for the process of interviewing among experts in Shariah field to determine rules and regulations behind the use of visuals in art.

\section{ACKNOWLEDGEMENT}

The authors would like to express their gratitude to Department of Fine Art, Faculty of Art \& Design, Universiti Teknologi MARA, Perak Branch, Seri Iskandar Campus; the Ministry of Higher Education Malaysia; and Research Management Centre, Universiti Teknologi MARA for providing and managing the fund, from Research Acculturation Grant Scheme (RAGS) [ref. no. 600-RMI/RAGS 5/3 (126/2014)].

\section{REFERENCES LIST}

Abdul Azib Hussain, (2012). Manhaj Ilmu Fiqah \& Usul Fiqah. Kuala Lumpur: Telaga Biru Sdn. Bhd.

Ahmadrashidi Hasan, 2010a. Islam and Art. Kertas kerja telah dibentangkan di forum Art Talk, Fakulti Seni Lukis dan seni Reka, UiTM, Melaka.

Ahmadrashidi Hasan, 2010b. Contemporary Islamic Painting In Malaysia 1980 - 2000. PhD. Thesis, Universiti Teknologi MARA, Malaysia. 
Dzul Haimi Md Zain, (1997). Safavid Qur'ans: Style and Illumination. PhD Thesis, University of Edinburgh, Scotland.

Dzul Haimi Md Zain, (2003). Seni Islam. Selangor: Univision Press Sdn. Bhd.

Galeri Wei-Ling, (2015). The Space Between. Katalog Pameran di Galeri Wei-Ling dari 1 April - 1 Jun 2015.

Hanifah Musa Fathullah Harun \& Mashita Abu Hassan (2012). Pendapatan Halal Dalam Konteks Maqasid Shariah. e-Proceeding International Halal Conference 2012, PWTC, Kuala Lumpur.

Ishak Ramli, Mohamad Noorman Masrek \& Muhamad Abdul Aziz Ab. Gani, (in press). Visual Art from the Perspectives of Islamic Shariah. Journal of Advanced Science Letter.

Ishak Ramli, Mohd Daud A. Rahim, Mohd Faizul Noorizan, Ponirin Amin, Rahman Amin, \& Mohd Suhaimi Tohid, (2014). Seni Visual dan Permasalahannya: Satu Perkaitan dengan Konsep Ad-Dharuriyyat dalam Maqasid Syariah. Proceeding World Conference on Islamic Thought, Casuarina@Meru Hotel, Perak

Ishak Ramli, Ponirin Amin, Rahman Amin, \& Mohd Suhaimi Tohid, (2012). Halal dan Seni Visual: Satu Hubungan dan Permasalahan di Malaysia. e-Proceeding International Halal Conference 2012, PWTC, Kuala Lumpur.

Jabatan Kemajuan Islam Malaysia, (n.d.). Garis Panduan dan Penjelasan Mengenai Seni Tampak dari Kaca Mata Islam. Retrieved on 1 September 2016, From Portal Jakim e-Fatwa. Website: http://www.efatwa.gov.my/

Khatijah Sanusi, (2000). Visual Art Education in Malaysia. Doctoral Dissertation, Temple University, USA.

Khatijah Sanusi, (2011). Era London: Sebelum dan Selepas. Raja'ah: Seni, Idea dan Kreativiti Sulaiman esa dari 1950-an - 2011. Kuala Lumpur: Balai Seni Visual Negara.

Muliyadi Mahamood, (1993). Kemekaran Jiwa Islam dalam Seni Lukis Malaysia Sezaman. Katalog Pameran Manifestasi Jiwa Islam dalam Senirupa Malaysia Sezaman: Balai Seni Lukis Negara.

Muliyadi Mahamood, (2001). Seni Lukis Moden Malaysia. Kuala Lumpur: Utusan Publication \& Distributors Sdn. Bhd.

Ocvirk, Stinson, Wigg, Bone, Cayton, (2009). Art Fundamentals Theory and Practice. Mc Graw Hill: School of Art, Bowling Green State University.

Osman Bakar, (1993). Kesenian Islam - Manifestasi Jiwa Islam dalam Kesenian. Exhibition Catalog, Festival Kesenian Islam, Istiqlal, Indonesia.

Sulaiman Esa, (1997). Islam and Politics of Art in Post-Independence Malaysia. Doctoral Dissertation, Temple University, USA.

Syamsul Anwar (1995), "Pandangan Islam Terhadap Kesenian", cited from Jabrohim and Saudi Berlian (eds.), Islam dan Kesenian, Yogyakarta : Majelis Kebudayaan Muhammadiyah Universitas Ahmad Dahlan dan Lembaga Litbang PP Muhammadiyah, p. 204-206.

Yusuf Qaradhawi, (1989). Halal dan Haram dalam Islam. Singapura: Pustaka Nasional Pte Ltd.

Wan Samiati Adriana Wan Mohd Daud, (2013). Study on the Malaysian Islamic Visual Art: The Contemporary View. International Journal of Education and Research Vol. 1, No. 12, December 2013. 